JURNAL NERS DAN KEBIDANAN (JOURNAL OFNERS AND MIDWIFERY) http://jnk.phb.ac.id/index.php/jnk

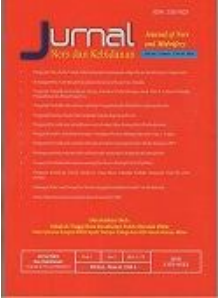

\title{
Oxygen Saturation (SPO2) of Covid-19 Patients
}

Ulfa Husnul Fata ${ }^{1}$, Lutvi Febriana ${ }^{2}$

${ }^{1,2}$ Nursing Department, STIKes Patria Husada Blitar, Indonesia

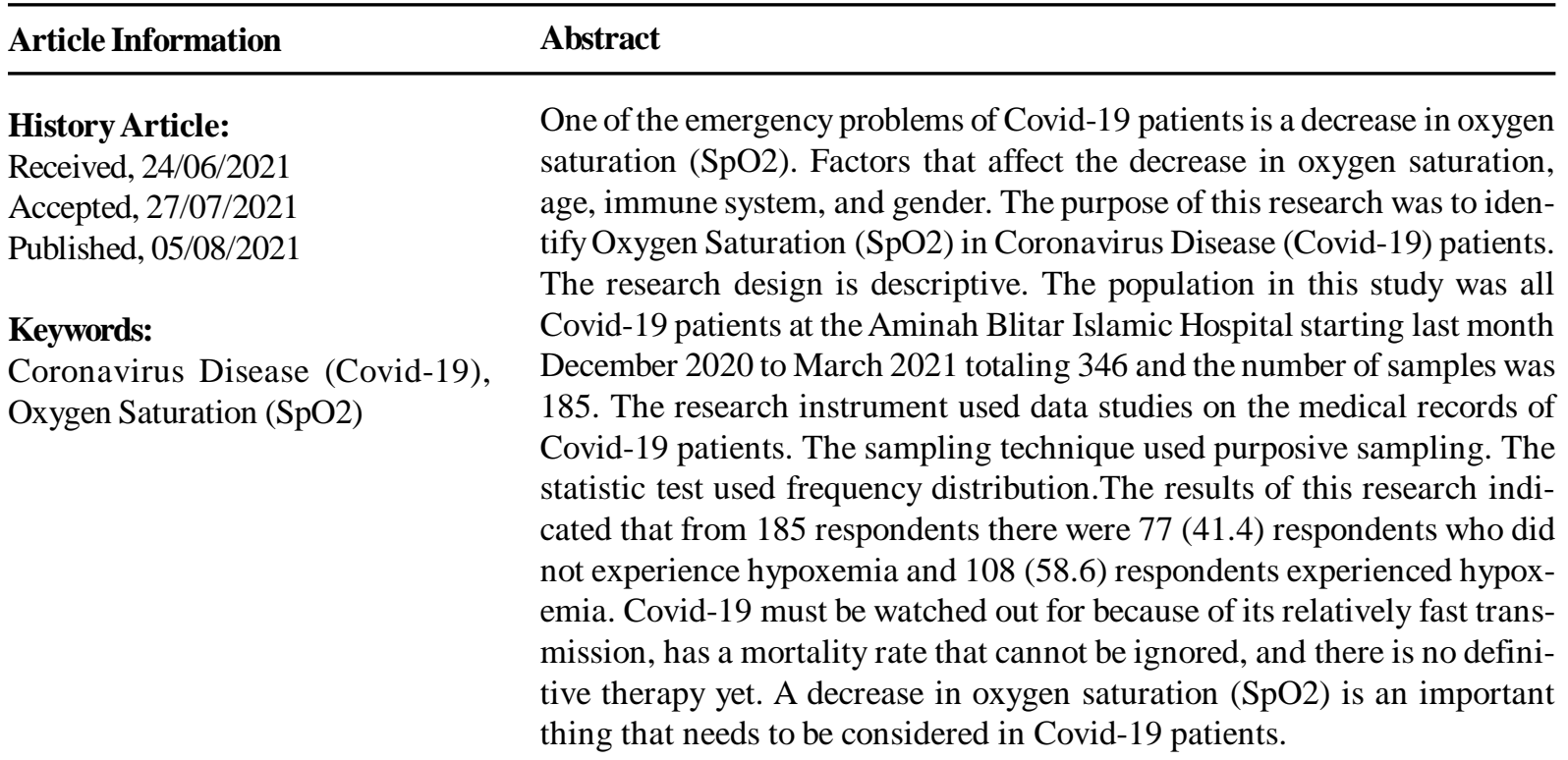

(C) 2021 Journal of Ners and Midwifery

\footnotetext{
${ }^{\square}$ Correspondence Address:

STIKes Patria Husada Blitar - East Java, Indonesia

P-ISSN : 2355-052X

Email:ulfaners@gmail.com

E-ISSN : 2548-3811

DOI: 10.26699/jnk.v8i3.ART.p290-294
}

This is an Open Access article under the CC BY-SA license (http://creativecommons.org/licenses/by-sa/4.0/) 


\section{INTRODUCTION}

In early 2020 , there was a new type of coronavirus, Severe Acute Respiratory Syndrome Coronavirus 2 (SARS-CoV-2) and the disease was called coronavirus disease 2019 (COVID-19). Until now, it has been confirmed that the coronavirus disease (COVID-19) outbreak has attacked 216 countries or regions in the world, including Indonesia(World Health Organization, 2020). Currently, the spread of SARS-CoV-2 (Severe Acute Respiratory Syndrome Coronavirus 2) from human to human is the main source of transmission so that the spread becomes more aggressive. Transmission of SARS-CoV-2 (Severe Acute Respiratory Syndrome Coronavirus 2) from symptomatic patients occurs through droplets released when coughing or sneezing.(Setiawan et al., 2020). There are 216 countries infected with COVID-19. The first COVID-19 case in Indonesia was reported on March 2, 2020, with 2 cases. East Java Province became the highest zone of positive patients, namely the city of Surabaya and Sidoarjo Regency.

The clinical symptoms of COVID-19 differ in each individual due to the influence of comorbid factors. Most COVID-19 patients who have comorbid diseases such as diabetes mellitus, hypertension, and cardiovascular disease are more likely to experience conditions that are easily deteriorating and even cause death (Ye et al., 2020).GOther symptoms of Covid-19 can affect the gastrointestinal system, the olfactory system (ears, nose and throat), the cardiovascular system, and the respiratory system. In the respiratory system, one of the symptoms that often appears is a decrease in oxygen saturation characterized by changes in respiratory frequency, depth or rhythm, breath sounds, cyanosis (in nails, lips, mucous membranes and skin), restlessness, anger, confusion, decreased level of consciousness, shortness of breath. or difficulty breathing (Enie Noviastari and Kusman Ibrahim, 2020). The Covid-19 virus itself is a virus caused by the SARS-Cov 2 virus, the SARS-Cov 2 virus contains an S protein that can cause spikes in cells so that the virus is easy to enter. After entering the cell through RNA (Ribonucleic Acid) it stimulates ACE 2 (Angiotensin Converting Enzyme 2) receptors. ACE 2 (Angiotensin Converting Enzyme 2) receptor serves to enter the virus into cells. So it affects the immunology of the host itself to decrease and an inflammatory response occurs in the host's own body. The inflammatory response then causes a cytokine storm that causes spots on the lungs so that the exchange of oxygen $(\mathrm{O} 2)$ in the lungs is disrupted and there is a decrease in oxygen saturation ( $\mathrm{SpO} 2)$. Decreased Oxygen Saturation ( $\mathrm{SpO} 2$ ) causes body tissues to lose a lot of oxygen so that it can cause death (Yuliana, 2020).

Oxygen saturation is one indicator of oxygenation status. Oxygen saturation is a measure of how much oxygen percentage hemoglobin is able to carry (Berman, 2016). The normal range for oxygen saturation is $>95 \%-100 \%$, although lower measurements may be normal in some people (Aini, 2014).

According to Berman, Snyder, Frandsen (2016) \&Klabunde (2015), the value of oxygen saturation is what percentage of all hemoglobin binding sites occupied by hemoglobin, pulse oximetry is a noninvasive tool that measures the oxygen saturation of arterial blood placed on the fingertips, the mother finger, nose, earlobe or forehead and pulse oximetry can detect hypoxemia before clinical signs and symptoms appear. According to (Fadlilah, 2017), a normal $\mathrm{SpO} 2$ value indicates that perfusion in the tissue is in good condition. Good perfusion is characterized by capillary refill time (CRT) and is also supported by normal oxygen saturation.

Based on the results of a preliminary study that was carried out at the Aminah Blitar Hospital, the average number of COVID-19 patients treated at Aminah Hospital from December 2020 to March 2021 was 346, most of them experienced a decrease in oxygen saturation $(\mathrm{SpO} 2)$, with an average age of 346. average 50 years. On January 22, 2021, Aminah Blitar Hospital was designated as one of the referral hospitals for COVID-19 in East Java, which was previously a buffer hospital.

Most of the deaths were caused by respiratory failure (sThe respiratory system is unable to carry out its function to distribute oxygen into the blood and organs, then remove carbon dioxide from the blood. This causes the body to lack oxygen as much as $45 \%$ and pneumonia (inflammation of the lungs caused by infection) as much as $55 \%$.

Based on the background of the problem above, the researcher is interested in researching "Saturation".Oxygen (SpO2) of Covid-19 Patients". The formulation of the research problem is how the oxygen saturation (SpO2) in Covid-19 patients is.

The purpose of this study was to identify Oxygen Saturation ( $\mathrm{SpO} 2)$ in Coronavirus Disease 
(COVID-19) Patients at Aminah Blitar Islamic Hospital.

The theoretical benefit of this research is that it is expected to provide nursing knowledge, especially Surgical Medical Nursing (KMB), as a contribution to science in the form of empirical data on Oxygen Saturation $(\mathrm{SpO} 2)$ in Coronavirus Disease (COVID-19) Patients at Aminah Blitar Islamic Hospital. The practical benefits of this research can be used as a basis for health workers in providing education to the public and providing nursing care to Covid-19 patients.

\section{METHODS}

This research was a quantitative research with a descriptive design. The population of was 185 samples at Aminah Islamic Hospital Blitar from December 2020 to March 2021. The sampling technique used purposive sampling.

The variable in this study was oxygen saturation (SpO2) of Covid-19 patients. This research did not take patients with comorbidities and $\mathrm{SpO} 2$ measurements while the patient was still in the Emergency Unit.

The data collection tool in this research was study data (case study) from patient medical records using a check list sheet. The data collection was carried out on June 15-18 June 2021. Data analysis used central tendency.

\section{RESULT}

\section{General data}

\section{Distribution of respondents by gender}

Table 1 Distribution of Respondents by Gender in Covid19 Patients at RSI Aminah Blitar

\begin{tabular}{llcc}
\hline No & Gender & Frequency & Percentage (\%) \\
\hline 1. & Man & 116 & 62.7 \\
2. & Woman & 69 & 37.3 \\
\hline & Total & $\mathbf{1 8 5}$ & $\mathbf{1 0 0 . 0}$ \\
\hline
\end{tabular}

Table 1. above, it can be seen that male respondents with Covid-19 were 116 respondents $(62.7 \%)$.

\section{Special Data}

Table 2. It is known that the respondents who experienced hypoxemia in Covid-19 patients were
108 respondents $(58.4 \%)$. While the normal amounted to 77 respondents (41.6\%).

Table 2 Oxygen Saturation (SpO2) in Covid-19 patients

\begin{tabular}{llcc}
\hline No & SpO2 (\%) & Frequency & Percentage (\%) \\
\hline 1. & $\begin{array}{l}\text { No Hypoxemia } \\
(95-100 \%)\end{array}$ & 77 & 41.6 \\
\hline 2. & $\begin{array}{l}\text { Hypoxemia } \\
(<95 \%)\end{array}$ & 108 & 58.4 \\
\hline & Total & $\mathbf{1 8 5}$ & $\mathbf{1 0 0 . 0}$ \\
\hline
\end{tabular}

\section{DISCUSSION}

\section{Oxygen Saturation}

Based on the results of the study, it was found that there were 108 patients with Covid-19 who experienced a decrease in $\mathrm{SpO} 2$ or hypoxemia $(58.4 \%)$ out of 185 patients. While the normal amounted to 77 respondents (41.6\%).

Oxygen saturation is the percentage of hemoglobin bound to oxygen in the arteries, normal oxygen saturation is between $95-100 \%$. Oxygen saturation (SO2) in medicine is often referred to as "SATS", to measure the percentage of oxygen bound by hemoglobin in the bloodstream. At low oxygen partial pressures, most of the hemoglobin is deoxygenated, meaning the process of distributing oxygenated blood from arteries to body tissues, normal oxygen saturation is between $95-100 \%$. Factors that affect the saturation value are Hemoglobin (HB), Circulation, Activity(Astuti \& Sulistyo, 2019).

According to (Wang, 2020) the attachment and entry of viruses into host cells is mediated by Protein $S$ on the surface of the virus. Protein $S$ is the main determinant in infecting the host species as well as the tropical determinant. In SARS-CoV, protein $\mathrm{S}$ itself is a toxin that can cause spikes in cells that are easy for viruses to enter by binding to receptors on host cells, namely the enzyme ACE-2 (angiotensin-converting enzyme 2). according to(Yuliana, 2020). After successfully entering the cell via RNA (Ribonucleic Acid)subsequent translation of gene replication from the viral RNA genome. Furthermore, replication and transcription where the synthesis of viral RNA through translation and assembly of the viral replication complex. The next stage is the assembly and release of the 
virus. After transmission occurs, the virus enters the upper respiratory tract and then replicates in upper respiratory epithelial cells (performing its life cycle). After that it spreads to the lower respiratory tract which stimulates ACE 2 (Angiotensin Converting Enzyme 2) receptors, especially in the lungs. ACE 2 (Angiotensin Converting Enzyme 2) The receptor serves to enter the virus into the cell. So it affects the immunology of the host itself to decrease and an inflammatory response occurs in the host's body. The inflammatory response then causes a cytokine storm to increase, resulting in a collection of secretions resulting in spots on the lungs, disrupting the exchange of oxygen $(\mathrm{O} 2)$ in the lungs and decreasing oxygen saturation ( $\mathrm{SpO} 2)$. according to(Ali et al., 2020), the factors that affect the decrease in oxygen saturation are age, body resistance, and gender.

According to (Siagian, 2020) the age category of the elderly who are susceptible to Covid-19 is not uniform, there are those who state that the elderly aged $>80$ years are at high risk of contracting the Corona Virus (according to Chinese researchers), the elderly aged $>50$ years (according to the Mayor of New York) there are even Indonesian researchers stated that people aged 45-65 years were vulnerable to being exposed to the Corona Virus. According to (Malik, 2019) the elderly often experience decreased body resistance. Changes in immune function (immune) due to the effects of aging and the presence of immunosense in the elderly cause susceptibility to infection in neutralizing viral infections. According to (Hidayati, 2020) male residents and residents aged over 46 years, especially 60 years and over, are vulnerable to Covid19.

Patients with Covid-19 in the elderly (46-65 years) $43.2 \%$, of $43.2 \%$ in the elderly ( $46-65$ years) $45.7 \%$ were male compared to female $(39.1 \%)$. According to (Fatmah, 2006) men are more susceptible to Covid-19. One of them is because the decrease in the number of $\mathrm{B}$ cells and $\mathrm{T}$ cells in elderly men is greater than women. As a result, the resulting immune response is not too adequate. In addition, testosterone affects the expression of TMPRSS2, which plays an important role in the process of entering the SARS-CoV-2 virus into body cells. With age, a person's immune system is increasingly experiencing dysfunction. As a result, elderly Covid-19 patients are increasingly vulnerable to experiencing "cytokine storms" that can cause problems in various organs of the body and trigger respiratory failure.

Hypoxemia is a condition of decreased oxygen content $(\mathrm{O} 2)$ in arterial blood. Hypoxia is a condition of inadequate supply of $\mathrm{O} 2$ to the tissues. Hypoxia can be caused by hypoxemia or impaired blood supply to tissues. Hypoxemia can be caused by impaired oxygenation, anemia or decreased affinity of hemoglobin $(\mathrm{Hb})$ for O2. Impaired oxygenation is hypoxemia resulting from low $\mathrm{O} 2$ transfer from the lungs to the bloodstream, which is characterized by low $\mathrm{O} 2$ partial pressure $(\mathrm{PaO} 2<80$ $\mathrm{mmHg}$ ) (Dewi et al., 2019).

Partial pressure describes the pressure of a dissolved gas to the total pressure of the gas mixture (such as the pressure of oxygen gas to the total pressure of the gas mixture in the air). The partial pressure of arterial blood oxygen as a marker of oxygenation in arterial blood can be measured from blood gas analysis. Hypoxia causes multiple organ damage and if not treated properly can result in death. Hypoxia causes an increase in the number of nucleated erythrocytes (EB) through an erythropoietin-mediated mechanism to compensate for the increased oxygen demand. Increased erythropoiesis releases immature erythrocytes into the blood circulation(Dewi et al., 2019). So the decrease in oxygen saturation $(\mathrm{SpO} 2)$ is very dangerous.

\section{CONCLUSION}

The conclusions in this study were that the number of Covid-19 patients who experienced a decrease in $\mathrm{SpO} 2$ was 108 respondents (58.6\%) with normal values of oxygen saturation $(95 \%$ $100 \%)$ and hypoxemia ( $<95 \%)$. It was found that patients exposed to COVID-19 experienced a decrease in $\mathrm{SpO} 2$ amounting to 108 patients $(58.4 \%)$ from 185 patients. While the normal amounted to 77 respondents $(41.6 \%)$.

\section{SUGGESTION}

Health workers are expected to serve as material for educating the public that people exposed to COVID-19 are at risk of experiencing a decrease in $\mathrm{SpO} 2$.

Further research is expected to become basic data for further research in carrying out research on oxygen saturation $(\mathrm{SpO} 2)$ in patients with Covid19 with a larger population. 


\section{REFERENCES}

Ali, R. M., Tutupoho, R. V., \& Chalidyanto, D. (2020). No Title. 4, 48-55.

Ayu, G., Laksmi, P., \& Sari, P. (2019). Jurnal Sains dan Kesehatan. 2(4), 548-557.

Astuti, W., \& Sulistyo, F. A. (2019). Hubungan Intensitas Tindakan Suction Dengan Perubahan Kadar Saturasi Oksigen Pada Pasien Yang Terpasang Ventilator Di Ruang Icu RSUD Kota Bogor. Jurnal Ilmiah Wijaya, 11(2), 134-142.

Dewi, C. J. S., Yaswir, R., \& Desywar, D. (2019). Korelasi Tekanan Parsial Oksigen Dengan Jumlah Eritrosit Berinti Pada Neonatus Hipoksemia. Jurnal Kesehatan Andalas, 8(1), 76. https://doi.org/ 10.25077/jka.v8i1.973

Enie Noviastari, Kusman Ibrahim, D. an S. R. (2020). Dasar-Dasar Keperawatan (9th ed.). Elsevier.

Francisco, A. R. L. (2018). Tinjauan Kepustakaan Sistem Pernapasan - Universitas Udayana. Journal of Chemical Information and Modeling, 53(9), 16891699.

García Reyes, L. E. (2013). Journal of Chemical Information and Modeling, 53(9), 1689-1699.

Gede, I. P., \& Agung, I. G. (2017). Terapi oksigen (o 2 ). 2-28.

Kemenkes RI. (2020a). No Title. Indonesia Dalam Menghadapi Pandemi Covid-19.

Notoatmodjo. (2018). Metode Penelitian Kesehatan. Rineka Cipta.

Nursalam. (2020). Metodologi Penelitian Ilmu Keperawatan (5th ed.). Salemba Medika.

Putri, R. N. (2020). Indonesia dalam Menghadapi Pandemi Covid-19. 20(2), 705-709. https://doi.org/ 10.33087/jiubj.v20i2.1010

Putu, N., Putra, P., Listyoko, A. S., \& Christanto, A. (2020).
Sebagai Prediktor Derajat Keparahan Pasien COVID-19 Rawat Inap. 253-259.

Setiawan, F., Puspitasari, H., Sunariani, J., \& Yudianto, A. (2020). Molecular Review Covid19 from the Pathogenesis and Transmission Aspect. Jurnal Kesehatan Lingkungan, 12(1si), 93. https://doi.org/ 10.20473/jkl.v12i1si.2020.93-103

Siagian, T. H. (2020). Corona Dengan Discourse Network Analysis. Jurnal Kebijakan Kesehatan Indonesia, 09(02), 98-106.

Suherlim, D., Lubis, L., \& Permana, H. (2021). Korelasi kadar hemoglobin dengan saturasi oksigen pada guru besar Universitas Padjadjaran. 1(2), 26-29. https://doi.org/10.36675/baj.v1i2.15

Susilo, A., Rumende, C. M., Pitoyo, C. W., Santoso, W. D., Yulianti, M., Sinto, R., Singh, G., Nainggolan, L., Nelwan, E. J., Khie, L., Widhani, A., Wijaya, E., Wicaksana, B., Maksum, M., Annisa, F., Jasirwan, O. M., Yunihastuti, E., Penanganan, T., New, I., ... Cipto, R. (2020). Coronavirus Disease 2019/: Tinjauan Literatur Terkini Coronavirus Disease 2019/: Review of Current Literatures. 7(1), 45-67.

Utama, S. A. (2018). Buku Ajar Keperawatan Medikal Bedah Sistem Respirasi. CV BUDI UTAMA.

Winarsih, D. S. (2020). Characteristics of Anosmia Cases in Covid-19 Patients/ : a Systematic Review. 1926.

World Health Organization, 2020. (2020). Jurnal Sains dan Kesehatan. Jurnal Sains Dan Kesehatan, 2(4), 548 557.

Yuliana, Y. (2020). Corona virus diseases (Covid-19): Sebuah tinjauan literatur. Wellness And Healthy Magazine, 2(1), 187-192. https://doi.org/10.30604/ well.95212020 